
Academician of the Academy of Economic Sciences of Ukraine Doctor Honoris Cause of Banking University (Kyiv)

Poznań University of Economics and Business Head of Chair in Economic and Local Government Policy Poznań, Republic of Poland; e-mail:k.pajak@ue.poznan.pl

Bożena Kamińska

Parliament of the Republic of Poland Member of Parliament of the Republic of Poland Vice Chairmen of the Board of Polish-Ukrainian Parliamentary Group Warsaw, Republic of Poland ; e-mail:biuro@bozenakaminska.pl

Алексей Квилинский

Ph.D. (Economics) Corresponding Member of the Academy of Economic Sciences of Ukraine Poznań University of Economics and Business Adjunct of Chair in Economic and Local Government Policy Poznań, Republic of Poland Donetsk National Technical University Associate Professor at the Department of Business Economics Pokrovsk, Ukraine Institute of Industrial Economics of NAS of Ukraine Doctor of Science Studies Kyiv, Ukraine e-mail:oleksii.kvilinskyi@ue.poznan.pl

\title{
MODERN TRENDS OF FINANCIAL SECTOR DEVELOPMENT UNDER THE VIRTUAL REGIONALIZATION CONDITIONS
}

Abstract. The article analyzes the current trends in the development of the financial sector under the virtual regionalization conditions. Based on empirical research with regard to global financial institutions, options for addressing the problems of micro, meso and macro levels in the long-term prospect of the world economy have been suggested, in relation to the technological cycle of Kondratiev waves. In the study, research results of both the economists engaged in the problem of sustainable socio-environmental-economic development under the modernization and post industrialization conditions, and researchers of adjacent scientific fields. The analysis results of the present article allow for the discovery of new horizons and areas for scientific analysis to bring together science and practice, as well as for creating conditions for accelerating scientific and technological progress.

Key words: modern trends, financial sector, competence delegation, virtual regionalization, Kondratiev waves, globalization.

JEL classification: E00, G00, O100, O400, L00

Formulas: 0; fig.: 4, tabl.: 1, bibl.: 42

Пайонк Кажімєж⿻

д.е.н., професор, академік Академії економічних наук України почесний професор ДВНЗ «Університет банківської справи» (м. Київ)

Державний економічний університет в Познані завідувач кафедри економічної політики та самоврядування м. Познань, Республіка Польща;e-mail:k.pajak@ue.poznan.pl 
Каміньська Божена

Сейм Республіки Польща

депутат Сейму Республіки Польща

віче-голова правління Польсько-украйнської парламентарної групи м. Варшава, Республіка Польщяа; e-mail:biuro@bozenakaminska.pl

Квілінський Олексій

к.е.н., член-кореспондент Академії економічних наук України

Державний економічний університет в Познані

ад'юнкт кафедри економічної політики та самоврядування

м. Познань, Республіка Польщза

ДВНЗ «Донеиький національний технічний університет»

дочент кафедри економіки підприємства, м. Покровськ, Україна

докторант Інституту економіки промисловості НАН України

м. Київ, Україна; e-mail: oleksii.kvilinskyi@ue.poznan.pl

\section{СУЧАСНІ ТЕНДЕНЦІЇ РОЗВИТКУ ФІНАНСОВОГО СЕКТОРУ В УМОВАХ ВІРТУАЛЬНОÏ РЕГІОНАЛІЗАЦІЇ}

Анотація. У статті проаналізовані сучасні тенденції розвитку фінансового сектора в умовах віртуальної регіоналізації. На підставі емпіричних досліджень відносно глобальних фінансових інститутів, запропоновано варіанти розгляду проблем мікро-, мезо- і макрорівнів в перспективі розвитку світової економіки, у співвідношенні з циклами технологічних хвиль Кондратьєва. У роботі використано результати досліджень як економістів, що займаються проблемою стійкого соціально-еколого-економічного розвитку в контексті умов модернізації та постіндустріалізації, так і дослідників суміжних наукових напрямів. Результати аналізу цієї статті припускають відкриття нових горизонтів і напрямів для проведення наукового аналізу з метою об'єднання науки та практики, а також створення умов для прискорення науково-технічного прогресу.

Ключові слова: сучасні тенденції, фінансовий сектор, делегування компетенцій, віртуальна регіоналізація, хвилі Кондратьєва, глобалізація

Формул: 0; рис.: 4; табл.: 1; бібл.: 42

Пайонк Казимежс

д.э.н., профессор, академик Академии экономических наук Украины почетный профессор ДВНЗ «Университет банковского дела» (2. Киев)

Государственный экономический университет в Познани заведуюший кафедрой экономической политики и самоуправления 2. Познань, Республика Польша; e-mail: k.pajak@ue.poznan.pl

Каминьска Божена

Сейм Республики Польша депутат Сейма Республики Польша вице-председатель Польско-украинской парламентарно группь 2. Варшава, Республика Польша; e-mail: biuro@bozenakaminska.pl

Квилинский Алексей к.э.н., член-корреспондент Академии экономических наук Украинь

Государственный экономический университет в Познани адъюнкт кафедры экономической политики и самоуправления г. Познань, Республика Польша 
ГВУЗ «Донеикий национальный технический университет»

дочент кафедры экономики предприятия, г. Покровск, Украина

докторант Института экономики промышленности НАН Украины

г. Киев, Украина; e-mail: oleksii.kvilinskyi@ue.poznan.pl

\section{СОВРЕМЕННЫЕ ТЕНДЕНЦИИ РАЗВИТИЯ ФИНАНСОВОГО СЕКТОРА В УСЛОВИЯХ ВИРТУАЛЬНОЙ РЕГИОНАЛИЗАЦИИ}

Аннотация. В статье проанализированы современные тенденции развития финансового сектора в условиях виртуальной регионализации. На основании эмпирических исследований в отношении глобальных финансовых институтов, предложены варианты рассмотрения проблем микро-, мезо- и макро- уровней в перспективе развития мировой экономики, в соотношении с циклом технологических волн Кондратьева. В работе использованы результаты исследований как экономистов, занимающихся проблемой устойчивого социально-эколого-экономического развития в контексте условий модернизации и постиндуастрализации, так и исследователей смежных научных направлений. Результаты анализа в данной статье предполагают открытие новых горизонтов и направлений для проведения научного анализа с целью объединения науки и практики, а также создания условий для ускорения научно-технического прогресса.

Ключевые слова: современные тенденции, финансовый сектор, делегирование компетенций, виртуальная регионализация, волны Кондратьева, глобализация.

Формул: 0; рис.: 4; табл.: 1; библ.: 42

Introduction. In the period of fundamental transformation of the global economic system and acceleration of the pace of scientific and technological progress, which are caused, according to the Kondratiev theory, by the development of a new, sixth, technological paradigm in the economy [1, p. 101], the question of the effective use of limited resources becomes ever more relevant [2, pp. 36-38]. In particular, the latter is related to the formation and implementation of neo-industrial model of development and functioning of the world economy [3, pp. 983-999; 4; 5, p. 27]. In turn, there is no denying the fact that the dominant role in managing the global development processes is played by such world-class financial institutions as the World Bank, the Federal Reserve System, the European Bank for Reconstruction and Development, Standard Chartered Bank (Hong Kong) Limited, Industrial and Commercial Bank of China, China Construction Bank, Agricultural Bank of China or the Bank of China. Along with this, the investigations of the charitable organization «Oxfam International» indicate that the most of the Earth's wealth is concentrated in the possession of less than $1 \%$ of the planet's population [6].

Thus, considering the trend of monopolization of the economic interests of the majority by the minority (99\%: 1\%) and with the help of financial and credit economic management tools, the economic science is confronted with the problem of global market de-monopolization with the purpose of socio-economic environment stabilization. To confirm the relevance of the above mentioned statement, it is necessary to bring examples of studies by prominent scientists and economists with a worldwide reputation, related to the analysis of the problem, namely George Soros, Joseph Stiglitz, Zbigniew Brzeziński, Henry Kissinger, who consider socio-economic disparities to be the main problem of society in the period of intense globalization, 
caused, to a greater extent, by the development of information technology (the fifth technological paradigm [6, pp. 22-25.]).

Literature review and the problem statement. Correlation of the factors of sustainable socio-economic development is described in the works of a great number of scientists. For example, Khobta V.M., Popova O.Y., Meshkov A.V., Kravchenko S.I., Bondareva I.A. [7; 8, pp. 14-21; 9, pp. 236-244] consider the solution to the issue of sustainable development by means of strengthening and enhancing the innovation processes at micro level.

In turn, Ivanov S.V., Lyashenko V.I., Tolmacheva A.F., Blagodarniy A.I., Kharazishvili Y.M. [10, pp. 9-34; 11, pp. 18-23; 12, pp. 30-37; 13, pp. 3-21] examine the issue of socio-economic stability from the standpoint of small and medium-sized businesses development, taking into account the factors of regional peculiarities.

Research on global functioning and development of the economy has been carried out and covered in the works of such authors as Kosolapov N.A., Dementiev V.V., Dalevskaya N.M., David P., Foray D., Hall B., Vishnevskyi V.P., Lyashenko V.I., Warwick K., Vodolazskaya N.V. [14; 15, pp. 50-54; 16, pp. 1-5; 17, pp. 9-24; 4, p. 57; 19], and many other scientists.

In particular, the problems of the financial sector development, the analysis of which has been carried out in relation to the global transformation processes, is represented in the works of many scientists, notably the works of $[1 ; 20$, pp. 129-135; 21 , pp. 37 ; 22, pp. 287-303; 23, pp. 87-102; 24, pp. 62-79] and others. However, the question of stability and uniformity of the socio-economic development still remains unresolved, which is caused by philosophical view of the process of civilization development, rather than by the point of view of economic analysis, where the financial sector plays one of the most significant roles.

Thus, in the present article, it is proposed to consider the development of the financial sector as a key element of the economic system from the point of view of scientific and technical progress prospects.

The study is aimed at ascertaining the impact of competence delegation factor on the future development prospects of the financial sector. In turn, the delegation of competence is referred to as redistribution of the administrative functions and authorities by means of defining compromise and consensus with the use of models of strategic sinergetization and competitiveness optimization [25, pp. 70-77].

Research results. The main hypothesis of the present article is as follows: improving the functioning of the financial sector at the expense of transformational and transactional costs in the long term transformation of the financial and credit system and formation of a new order of functioning of the economy, as well as emergence of the added value, using the advantages of small businesses in relation to corporate governance.

To achieve this goal, theoretical and empirical methods have been used in the study. In particular, systematic approach has been applied when addressing the functioning of the financial sector within the global economic system context, whereas the method of abstraction has been applied by analysis and synthesis, induction and deduction of economic phenomena. The formalization of the analogy has been used to systematize the results obtained in the studies. 
The article consists of three parts. The first part explores the issues of the economic system functioning at the global level, financial sector in particular. For the analysis, data of the World Bank and international research institutions have been used. In the second part, modern approaches to solving problems related to socioeconomic stability are presented in the context of the motivational financial factor when delegating financial competence in the course of transformation of the technological structure of global economic system. Finally, in the last part of this article, solutions to the set tasks are proposed to achieve the purpose of the study.

The importance of financial and credit policy in the functioning of the modern economic system cannot be overestimated. Financial institutions with real instruments of impact on the economy form their strategies based on the principles of maximizing profits, which, in principle, is logical for any business entity.

However, with the question of sustainable economic development on a global scale getting more relevant, which is caused mainly by the achievements of scientific and technological progress and global warming, the severity of the social inequality has been revealed. As noted above, the ratio of $99 \%: 1 \%$ of the total number of people on the planet, and a corresponding distribution of all resources is, respectively: $99 \%$ $<50 \%$ and $1 \%>50 \%$ [6]. In turn, the retention of this situation by the minority is currently possible due to the monetary policy of global corporations and deterring the use of new technologies in the economy, the confirmation of real opportunities of which does not require a particular argument.

According to the World Bank [26, p. 3], the development of digital technologies leads to a decrease in global productivity and increase in global inequality. To analyze this phenomenon, it is proposed to abstract and examine the problem from the standpoint of determining the concentration of financial resources. Taking into account the fact that new technologies use such a competitive advantage as "temporary monopoly", let us consider the technological development as a structure of technological paradigms (Fig. 1) in accordance with the Kondratiev cycles (Fig. 2).

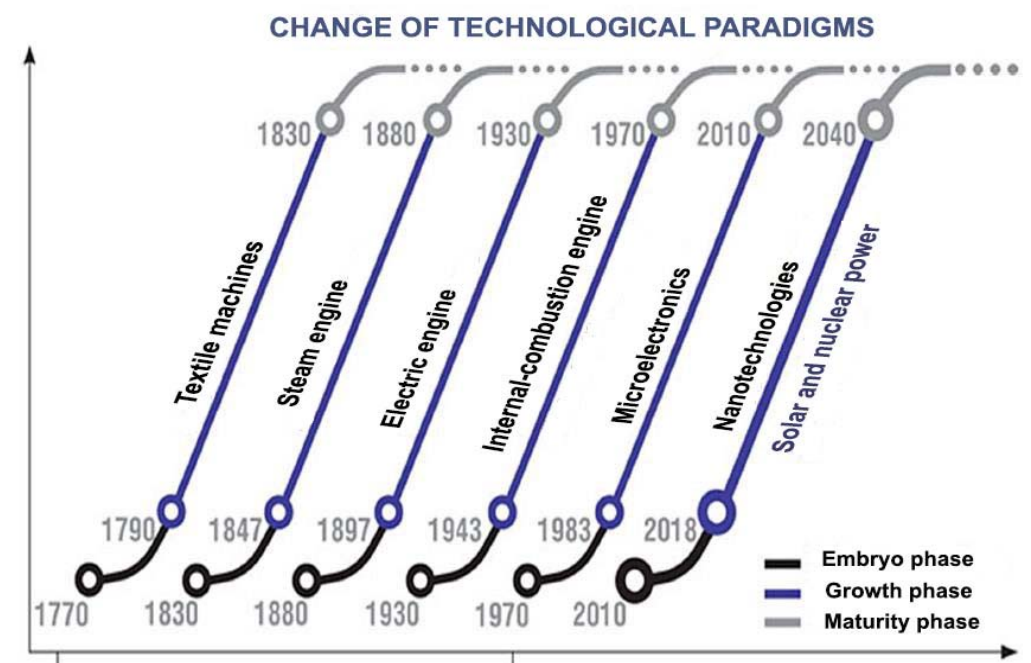

Figure 1. Change of technological paradigms

Source: complied by the author based on own research [1, pp. 101-104] 


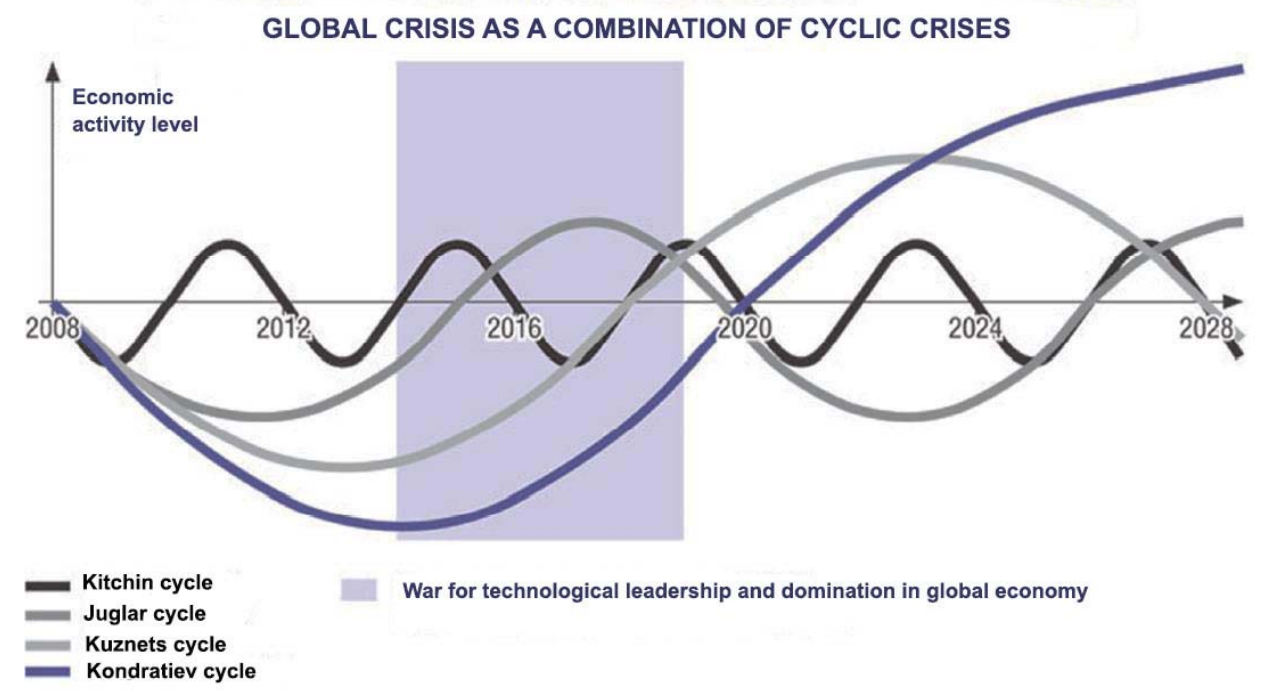

Figure 2. Global crisis and the state of economic activity in the first third of the $21^{\text {st }}$ century

Source: complied by the author based on own research $[5$, p. 12]

Based on the above information, it can be assumed that the fifth and sixth technological paradigms may well have a significant potential, in particular for the development of the financial sector. However, the capital concentration of the financial sector, while being its foundation, operates in the sector of energy resources. Figure 3 clearly demonstrated a global trend of increasing energy consumption. It should also be noted that the development of alternative energy could be considered as the proof of the beginning of Kondratiev's sixth wave.

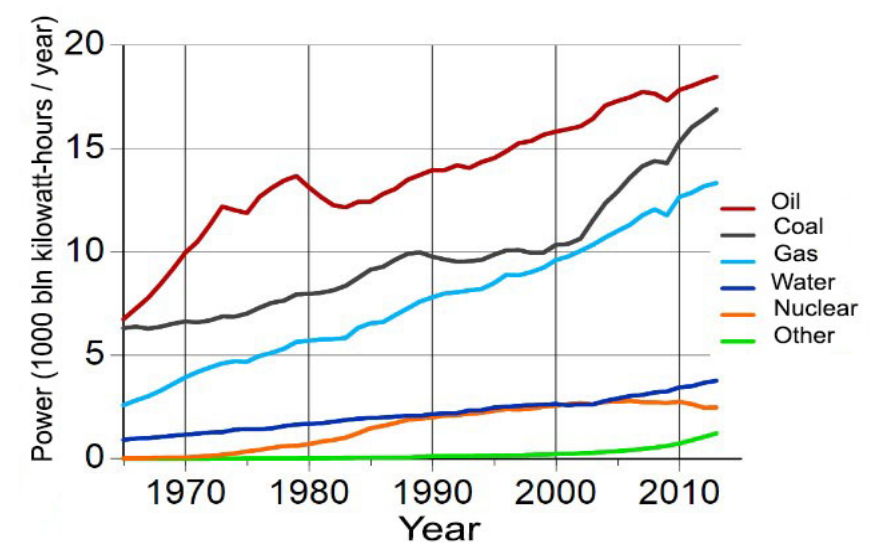

Source: [27]

Figure 3. Global energy consumption

The development of alternative energy sources is equally important for the European Union [28]. However, first, in the programs of strategic development an emphasis is made by the economists on energy security, given the instability of international politics regarding the distribution of energy resources.

Thus, having analyzed the state of the global economic system, development vectors and sources (concentration) of capital for the development of the financial sector have been selected. 
So, returning to analyzing the problem of social and economic sustainability, let us consider information technology as a tool for adaptation and implementation of technologies of the $5^{\text {th }}$ and $6^{\text {th }}$ paradigms in the structures of economic systems of various region scales.

Today, the development of information technologies (the $5^{\text {th }}$ paradigm) is transforming the economic environment, thereby defining new development directions, including those for the financial and credit system. With the advent of the Internet, virtual reality, digital technologies, the speed of technological progress has increased significantly. This thesis, looked at through the prism of the information speed factor, does not cause any doubts.

Motivational components for the development can be assumed as the ratio of 100 to 1 , where 100 is the conditional potential speed of economic development of the majority ( $99 \%$ of the population owning $50 \%$ of all resources), and 1 is the speed of implementation of innovative technologies at the moment (under other constant equal conditions).

In turn, according to the World Bank, in 2015 there were 3.2 billion of Internet users, of which 1.1 billion are using high-speed Internet [26, p. 3]. Hence, almost half of the world's population can use modern information technologies in the comfort of their homes.

Consequently, a new organizational form of economic and political system virtual regionalism - may enter the political game [29, pp. 22-24], prerequisites of which are shown in Fig. 4. This socio-economic phenomenon was initially investigated in the economic systems of cross-border environment, where administrative borders were less important than economic relations [30].

Thus, considering the phenomenon of virtual regionalization as one of the modern forms of integrating people, it makes sense to quote a well-known political and economic futurist George Friedman: "If anyone had said in 1950 that the world's great economic powerhouses a half century later would be Japan and Germany, ranked second and third, that person would have been ridiculed. If you argued in 1970 that by 2007 China would be the world's fourth-largest economic power, the laughter would have been even more intense. But it would have been no funnier than arguing in 1800 that the United States by 1900 would be a world power. Things change, and the unexpected should be expected." [31, p. 41].

Returning to Kondratiev's waves (see Fig. 1), it is assumed that the embryo phase of the sixth technological paradigm is within the span of 2010-2018. Consequently, it can also be assumed that reaching the bifurcation point of the new technological paradigm in the economic system may facilitate the transformation not only in the economy, but also in its scientific perception.

"The cheapest pride is the national pride. It uncovers in an infected subject a lack of individual qualities that he could be proud of, because otherwise he would not refer to things that he shares with millions of people. He, who possesses significant personal advantages, constantly watching his nation first notices its shortcomings. But a poor man having nothing that he could be proud of, grabs the only possibility, and is proud of the nation he belongs to; he is ready to protect all its disadvantages and stupidity with affection "[32, p. 189]. 


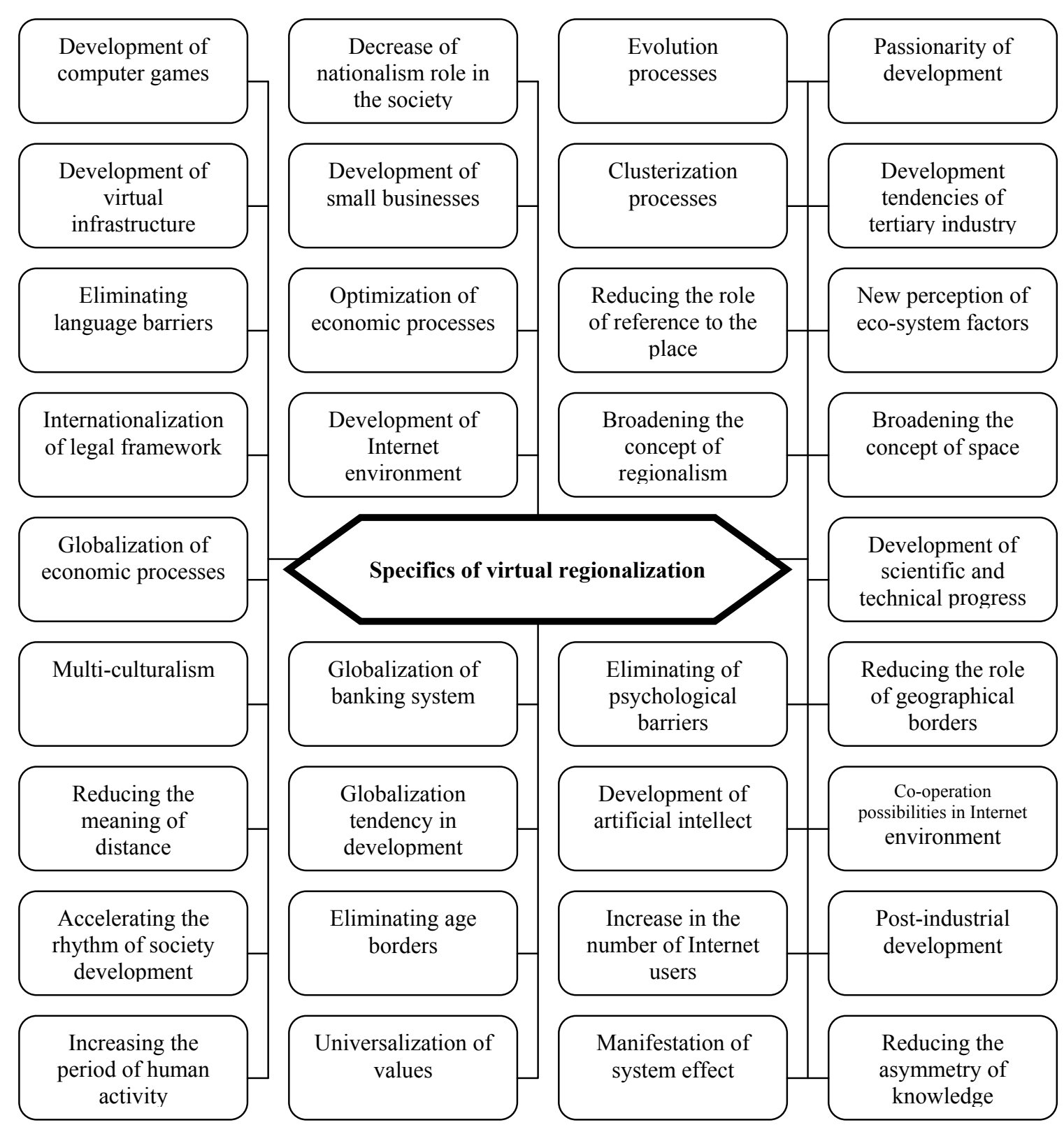

Figure 1. - Specifics of virtual regionalization

Source: compiled by the authors based on own researches

The above-cited statement of Schopenhauer is the basis of the multiculturalism policy in the current period of globalization. However, on the other hand, examples of "rootless cosmopolitanism" [33] are known to the history, where the legal basis makes a human fully dependent on the political system.

Thus, resolving the issue of national identity and overcoming various kinds of limits in the development, with the formation of virtual regionalism, let us move on to the final part of our study, namely, the definition of prerequisites for the effective use of instruments of financial sector competence delegation in global strategic perspective.

Systematizing the arguments listed in Table 1, it is necessary first to focus on financial sector competence delegation. We are talking about the setting of the 
process direction from the concentrated capital $(50 \%)$ by $1 \%$ of owners to the introduction of technologies of the $5^{\text {th }}$ and $6^{\text {th }}$ paradigms using the potential of the majority (99\%) and the existing market conditions in the current global economic system.

Economic scales of the minority and majority (1:99 - working class and capitalists), in the corresponding relation, by analogy, have the properties of small and large forms of incorporation with special features inherent in them. Figuratively, the capitalists owning assets in the form of technologies of the $5^{\text {th }}$ and $6^{\text {th }}$ paradigms, through the exploitation of the working class, using the reorganization of the financial sector (delegated competencies) and using the Internet environment, are capable of clustering the subjects of small business (virtual regionalism); they have an unprecedented opportunity of augmentation of their capital that can function and develop in the direction of cognitive technologies, and as well as increase the share of the $5^{\text {th }}$ and $6^{\text {th }}$ technological paradigms in the structure of the global economic system.

Table 1

Summary of the effective use of instruments of financial sector competence delegation in the period of the sixth technological paradigm.

\begin{tabular}{|c|c|c|c|}
\hline & Components & Majority & Minority \\
\hline 1 & Planet population & Majority $-99 \%$ & Minority $-1 \%$ \\
\hline 2 & $\begin{array}{l}\text { Total number of the world's } \\
\text { population } \sim 7,4 \text { bln people }[26, \\
\text { p. 3] }\end{array}$ & $99 \%$ - 7,326 bln people & $1 \%$ - 74 mln people \\
\hline 3 & $\begin{array}{l}\text { Disposal and ownership of } \\
\text { resources, including financial } \\
\text { [6] }\end{array}$ & $\begin{array}{c}<50 \%[6] \\
1 \%<0,51 \%\end{array}$ & $\begin{array}{l}>50 \%[6] \\
1 \%>50 \%\end{array}$ \\
\hline 4 & Economic scale $[11$, pp. 18-23] & $\begin{array}{l}\text { Small and medium } \\
\text { (micro) }\end{array}$ & $\begin{array}{l}\text { Large (meso, macro, } \\
\text { mega) }\end{array}$ \\
\hline 5 & $\begin{array}{l}\text { Prevailing forms of } \\
\text { incorporation }[11, \text { pp. 18-23] }\end{array}$ & $\begin{array}{l}\text { Small and medium } \\
\text { business }\end{array}$ & Corporate business \\
\hline 6 & $\begin{array}{l}\text { Capital management structure } \\
\text { [34] }\end{array}$ & $\begin{array}{c}\text { Horizontal } \\
\text { (clusters) } \\
{[10, \text { pp. } 9-34]}\end{array}$ & $\begin{array}{l}\text { Vertical (reflexive } \\
\text { management) }[35 ; 36]\end{array}$ \\
\hline 7 & $\begin{array}{l}\text { Main sources of added value } \\
{[37, \text { p. 178] }}\end{array}$ & Labor sales & Labor purchase \\
\hline 8 & $\begin{array}{l}\text { Technological paradigms used } \\
\text { in production process } \\
{[5, \text { pp. } 22-25]}\end{array}$ & $\begin{array}{c}\text { 1st, 2nd, 3rd, 4th } \\
\text { (perspective }-5^{\text {th }} \& 6^{\text {th }} \\
\text { paradigms) }\end{array}$ & $\begin{array}{l}\text { 5th, 6th (perspective } \\
- \text { cognitive } \\
\text { technologies of the } 7^{\text {th }} \\
\text { paradigm) }\end{array}$ \\
\hline 9 & Actual needs [38, pp. 108-112] & $\begin{array}{l}\text { Phisiological, security, } \\
\text { social affiliation }\end{array}$ & $\begin{array}{l}\text { Recognition and self- } \\
\text { actualization }\end{array}$ \\
\hline 10 & $\begin{array}{l}\text { Main principles of capital } \\
\text { preservation }[39 ; 40]\end{array}$ & Moral & Legal \\
\hline 11 & $\begin{array}{l}\text { Financial stability } \\
\text { development [41] }\end{array}$ & Stable & Unstable \\
\hline 12 & $\begin{array}{l}\text { Development rate (under other } \\
\text { equal conditions) [42] }\end{array}$ & High & Low \\
\hline
\end{tabular}


In turn, information asymmetry and psychological unpreparedness of most of the world's population can be an obstacle for the rational use of scientific and technological advances referring to the technologies of the $5^{\text {th }}$ and $6^{\text {th }}$ paradigms. However, the correlation between legal and moral principles of interpersonal relations can have a positive impact on the stabilization of socio-economic environments in the global economic system.

Conclusions. Thus, taking into account the information stated above in the present article, the following conclusions can be drawn:

1. The financial sector being one of the most important tools of the economic system, in the period of transformation of the latter, is also able to undergo changes in its forms and properties. Currently in the global economy, the basis of the financial sector is the energy sector, and the direction of development is investing in projects of innovative technologies implementation and in research areas of cognitive science.

2. Taking into account the economy development trends, including information and nanotechnologies, from the standpoint of the theory of Kondratiev cycles, it can be estimated that the strategic perspective of global development will have the following direction: from the improvement of an individual's personal space to social synergistic integration. In particular, we are talking about the formation of virtual regionalism.

3. In the period of transformational changes in the global economy, the financial sector competence, in order to increase the efficiency of capital utilization, will be delegated directly to a sponsored subject. An example of such kind of interaction algorithm in modern economy are structural funds to finance social infrastructure, where the main function of the efficient capital utilization - and along with it the competence of interaction between the capital owner and the subject of the project implementation - is delegated.

Consequently, the present studies can serve as an impetus for rethinking the model of economic functioning of the global economic system both for the economic scientists concerned with the issues of sustainable development in mega, macro, meso and micro systems and for the researchers of other related scientific fields.

\section{Література}

1. Глазьев, С. Ю. Стратегия опережающего развития России в условиях глобального кризиса: монография [Текст] / С. Ю. Глазьев. - Москва: Экономика, 2010. - 287 с.

2. Макконелл, К. Р. Экономикс: принципы, проблемы и политика [Текст] / К. Р. Макконел, С. Л. Брю. - Киев: Хагар-Демос, 1993. - 785 с.

3. Lever, W. F. Deindustrialisation and the Reality of the Post-industrial City [Text] // Urban Studies. - 1991. - V. 28. - N. 6. - P. 983-999.

4. Warwick, K. Beyond Industrial Policy: Emerging Issues and New Trends / Ken Warwick // KDI. $\quad$ - 2013. -27 p. - [Electronic resource]. - Available at: http://m.kdi.re.kr/data/download/attach/9894_0-1.pdf.

5. Ляшенко В. I. Україна XXI: неоіндустріальна держава або “крах проекту”?: монографія / В. І. Ляшенко, Є. В. Котов. - Київ: НАН України, Інститут економіки промисловості НАН України, Полтавський університет економіки і торгівлі, 2015. - 196 с.

6. Oxfam International. Pre-Davos report shows how rules privilege the richest $1 \%$ [Electronic resource]. - Available at: https://www.oxfam.org/en/pressroom/pressreleases/2016-0118/62-people-own-same-half-world-eu-needs-take-action-against-tax. 
7. Хобта, В. М. Активізація і підвищення ефективності інвестиційних процесів на підприємствах [Текст] / В. М. Хобта, О. Ю. Попова, А. В. Мєшков. - Донецьк: Норд-Пресс, 2005. - Донецьк. -343 с.

8. Кравченко С. И. Классификация инновационного потенциала / С. И. Кравченко // Экономист. - 2009. - № 8. - С. 14-21.

9. Бондарева, И. А. Особенности инвестиционно-инновационной направленности подготовки студентов в техническом вузе (на примере Донецкого региона) [Текст] / И. А. Бондарева, С. И. Кравченко, А. В. Мешков // Научно-технические ведомости СПбГПУ. Экономические науки. - 2015. - № 4 (223). - С. 236-244.

10. Ivanov, S. Właściwości modernizacji sfery przedsiębiorczej w kontekście państwowej polityki gospodarczej na Ukrainie [Tekst] / S. Ivanov, V. Lyashenko, A. Tolmachova, O. Kvilinskyi // Międzynarodowy Zbiór prac naukowych «Wspyłpraca Europejska». - 2016. - No 3. - S. 9-34.

11. Pajak, K. Operation of a business entity in the context of globalization / K. Pajak, V. Lyashenko, O. Kvilinskyi // Economic Herald of the Donbas. - 2015. - N. 4 (42), p. 18-23.

12. Благодарний, О.І. Дослідження впливу регіональних особливостей на розвиток суб’єктів малого підприємництва / О. І. Благодарний, Г. Ф. Толмачова, О. С. Квілінський // Економіка та право. - 2014. - № 1. - С. 30-37.

13. Харазішвілі, Ю. М. Теоретико-методологічні підходи до визначення внеску науково-технічного прогресу в моделі економічного зростання / Ю. М. Харазішвілі // Банківська справа. - 2010. - № 6. - С. 6-21.

14. Косолапов, Н. А. Глобализация: территориально-пространственный аспект / Н. А. Косолапов // Мировая экономика и международные отношения. - 2005. - № 6. - С. 3-13.

15. Дементьєв, В. В. Мінливість та сталість світового політико-економічного простору у контексті еволюції складних систем / В. В. Дементьєв, Н. М. Далевська // Наукові праці Донецького національного технічного університету. Серія: економічна. - 2011. - № 39-2. - С. $50-54$.

16. David, P. Smart Specialistaion. The concept. / P. David, D. Foray, B. Hall // Knowledge Economists Policy Brief. - 2007. - N. 9. - P. 1-5.

17. Промышленная политика и управление развитием промышленности в условиях системных дисбалансов: концептуальные основы: моногр. / В.П. Вишневский, А.И. Амоша, Л.А. Збаразская, А.А. Охтень, Д.Ю. Череватский; под общ. ред. В.П. Вишневского и Л.А. Збаразской / НАН Украины, Институт экономики промышленности. - Донецк, 2013. - 180 с.

18. Ляшенко, В. І. Еволюційні аспекти рефлексивних процесів в економічних системах на прикладі політичної історії україно-польських взаємовідносин / В. І. Ляшенко, О. С. Квілінський // Міжнародний Збірник наукових праць «Європейське співробітництво». 2016. - № 1. - С. 9-24.

19. Водолазська, Н. В. Технічні системи: сьогодні і завтра [Текст]: навч. посіб. для студ. за напрямком підготов. "Інженерна механіка" / Н. В. Водолазська; ДВНЗ "Донец. нац. техн. ун-т". - Донецьк: ДВНЗ "ДонНТУ", 2008. - 202 с.

20. Kaźmierczyk, J. Banks' expectations on banking labor market: the polish case, proceedings of the fourteenth international conference [Text] / J. Kaźmierczyk // American Society of Business and Behavioral Sciences. - Paris, 2011. - P. 129-135.

21. Kaźmierczyk, J. Human capital development in Polish banks [Text] / J. Kaźmierczyk // Baltic Rim Economies. - 2015. - N. 3. - P. 37.

22. Marcinkowska, M. Internetowe innowacje finansowe: agregatory i aukcje finansowe [Text] / M. Marcinkowska // Acta Universitatis Lodziensis, Folia Oeconomica. - 2009. - N. 224. P. 287-303.

23. Mitręga-Niestrój, K. Międzynarodowy system finansowy w ujęciu systemowym-jego efektywność oraz stabilność [Text] / K. Mitręga-Niestrój // Studia Ekonomiczne / Uniwersytet Ekonomiczny w Katowicach. - 2011. - N. 63. - P. 87-102. 
24. Solarz, J. K. Zarządzanie ryzykiem finansowym codzienności [Text] / J. K. Solarz // Bezpieczny Bank. - 2010. - N. 3 (42). - P. 62-79.

25. Кравченко, С. И. Оптимизация конкурентоспособности инновационного проекта в условиях стратегической синергетизации / С. И. Кравченко, А. С. Квилинский. // Вісник економічної науки України. - 2016. - №1. - С. 70-70.

26. Цифровые дивиденды. Группа Всемирного банка развития [Электронный ресурс] // Мировой банк. - 2016. - Режим доступа: http://wwwwds.worldbank.org/external/default/WDSContentServer/WDSP/IB/2016/01/13/0902

24b08405bbc0/1_0/Rendered/PDF/World0developm010dividends0overview.pdf.

27. BP: Statistical Review of World Energy [Electronic resource] // Workbook. - London: BP, 2012. - Available at: http://www.bp.com/en/global/corporate/energy-economics/statisticalreview-of-world-energy.html.

28. ACER/CEER Annual Report on the Results of Monitoring the Internal Electricity and Natural Gas Markets in 2013 [Electronic resource]. - Available at: http://www.europarl.europa.eu/meetdocs/2014_2019/documents/itre/dv/acer_market_monitoring_re port_2014_/acer_market_monitoring_report_2014_en.pdf.

29. Квилинский, А. С. Предпосылки возникновения виртуального регионализма / А. С. Квилинский, П. Блашчик, Б. Загерский // Матеріали доповідей міжнародної науковопрактичної конференції "Економіка в контексті інноваційного розвитку: стан та перспективи". - Ужгород: Видавничий дім «Гельветика», 2016. - Ч. 1. - С. 22-24.

30. Allison, R. Virtual regionalism, regional structures and regime security in Central Asia [Text] / R. Allison // Central Asian Survey. - 2008. - N. 27 (2). - P. 185-202.

31. Фридман, Д. Следующие 100 лет: Прогноз событий XXI века [Текст] / Д. Фридман. - Москва: Эксмо, 2010. - 335 с.

32. Шопенгауэр, А. Афоризмы житейской мудрости [Текст] / А. Шопенгауэр. Москва: АСТ, 2011. - 382 с.

33. Наджафов, Д. Г. Сталин и космополитизм. 1945-1953. Документы Агитпропа ЦК [Текст] / Д. Г. Наджафов, 3.С. Белоусова. - Москва: Материк, 2005. - 768 с.

34. Новиков, Д. А. Теория управления организационными системами [Текст] / Д. А. Новиков. - Москва: Московский психолого-социологический институт, 2005. - 584 с.

35. Лефевр, В. А. Рефлексия [Текст] / В. А. Лефевр. - Москва: Когито-Центр, 2003. $496 \mathrm{c}$.

36. Рефлексивные процессы в экономике: концепции, модели, прикладные аспекты: Монография; под ред. Р.Н. Лепы: НАН Украины, Ин-т экономики промышленности. Донецк: Апекс, 2010. - 306 с.

37. Маркс, К. Капитал. Критика политической экономии [Текст] / К. Маркс. - Москва: Издательство политической литературы, 1973. - 907 с.

38. Маслоу, А. Г. Мотивация и личность [Текст] / А. Г. Маслоу. - Санкт-Петербург: Издательский дом" Питер", 2008. - 352 с.

39. Стиглиц, Дж. Глобализация: Тревожные тенденции [Текст] / Джозеф Стиглиц; пер. с англ., прим. Г. Г. Пирогова. - Москва: Мысль, 2003. - 302 с.

40. Квілінський, О. С. Стратегічні аспекти формування можливостей покращення діяльності суб’ єктів малого бізнесу [Текст] / О. С. Квілінський // Схід. - 2012. - № 6 (120). C. 44-49.

41. Яблонский, Я. (2016). Децентрализация в Украине в условиях устойчивого развития [Текст] / Я. Яблонский, Н. Осадчая, А. Квилинский // Международный Сборник научных трудов «Европейское сотрудничество». - 2016. - № 8 (15). - С. 120-135.

42. Kharazishvili, Y. Impact of infrastructure component on socioeconomic approach to modernization of the region [Text] / Y. Kharazishvili, V. Liashenko, Y. Zaloznova, O. Kvilinskyi O. // "European Cooperation". - 2016. - N. 8 (15). - P. 108-119.

Стаття надійшла до редакиії 01.09.2016 Сайонк К., Каміньська Б., Квілінський О. 


\section{References}

1. Glaziev, S. Yu. (2010). Strategiya operezhayushchego razvitiya Rossii v usloviyah global'nogo krizisa: monografiya. Moskva: Ekonomika.

2. Makkonell, K. R., Bryu, S. L. (1993). Ekonomiks: principy, problemy i politika. Kiyev: Hagar-Demos.

3. Lever, W. F. (1991). Deindustrialisation and the Reality of the Post-industrial City. Urban Studies, 28, 6, 983-999.

4. Warwick K. Beyond Industrial Policy: Emerging Issues and New Trends. Available at: http://m.kdi.re.kr/data/download/attach/9894_0-1.pdf.

5. Liashenko, V. I., Kotov, E. V. (2015). Ukraina XXI: neoindustrialna derzhava abo "krakh proektu"?: monohrafiia. Kyiv: Instytut ekonomiky promyslovosti NAN Ukrainy, Poltavskyi universytet ekonomiky i torhivli.

6. Oxfam International. Pre-Davos report shows how rules privilege the richest $1 \%$. Available at: https://www.oxfam.org/en/pressroom/pressreleases/2016-01-18/62-people-own-samehalf-world-eu-needs-take-action-against-tax.

7. Khobta, V. M., Popova, O. Yu., Mieshkov, A. V. (2005). Aktivizaciya i pidvishchennya efektivnosti investicijnih procesiv na pidpricmstvah. Donec'k: Nord-Press.

8. Kravchenko, S. I. (2009). Klassifikaciya innovacionnogo potenciala. Ekonomist, 8, 14-21.

9. Bondareva, I. A., Kravchenko, S. I., Meshkov, A. V. (2015). Osobennosti investicionnoinnovacionnoj napravlennosti podgotovki studentov v tekhnicheskom vuze (na primere Doneckogo regiona). Nauchno-tekhnicheskie vedomosti SPbGPU. Ekonomicheskie nauki, 4 (223), 236-244.

10. Ivanov, S., Lyashenko, V., Tolmachova, H., Kvilinskyi, O. (2016). Features of modernization of entrepreneurial sphere in the context of the national economic policy in Ukraine. European Cooperation, 3 (10), 9-34.

11. Pajak, K., Lyashenko, V., Kvilinskyi, O. (2015). Operation of a business entity in the context of globalization. Economic Herald of the Donbas, 4(42), 18-23.

12. Blagodarnyi, A. I., Tolmachova, H. F., Kvilinskyi, O. S. (2014). Investigation of the impact of regional characteristics on the development of small businesses. Economics and Law, 1, $30-37$.

13. Kharazishvili, Yu. M., \& Dron Ye. V. (2015). Problems of integrated assessment of the level of economic safety of the state. Banking business, 1 (133), 3-21.

14. Kosolapov, N. A. (2005). Globalizaciya: territorial'no-prostranstvennyj aspect. Mirovaya ehkonomika i mezhdunarodnye otnosheniya, 6, 3-13.

15. Dementiev, V. V., Dalevska, N. M. (2011). Minlyvist ta stalist svitovoho politykoekonomichnoho prostoru u konteksti evoliutsii skladnykh system. Naukovi pratsi Donetskoho natsionalnoho tekhnichnoho universytetu. Seriia: ekonomichna, 39-2, 50-54.

16. David, P., Foray, D., Hall, B. (2007). Smart Specialistaion. The concept, Knowledge Economists Policy Brief, 9, 1-5.

17. Vishnevskij, V. P. (red.). Promyshlennaya politika $i$ upravlenie razvitiem promyshlennosti $v$ usloviyah sistemnyh disbalansov: konceptual'nye osnovy: monografiya. NAN Ukrainy, Institut ehkonomiki promyshlennosti, Doneck.

18. Lyashenko, V., \& Kvilinskyi, O. (2016). Evolutionary aspects of reflective processes in economic systems in case of political history of Ukraine-Polish relations. European Cooperation, 1, 9-24. Donetsk.

19. Vodolazska, N. V. (2008). Tekhnichni systemy: sohodni i zavtra, DVNZ "DonNTU”,

20. Kaźmierczyk, J. (2011). Banks' expectations on banking labor market: the polish case, proceedings of the fourteenth international conference. American Society of Business and Behavioral Sciences, PARIS, 129-135.

21. Kaźmierczyk, J. (2015). Human capital development in Polish banks. Baltic Rim Economies, 3, 37. 
22. Marcinkowska, M. (2009). Internetowe innowacje finansowe: agregatory i aukcje finansowe. Acta Universitatis Lodziensis. Folia Oeconomica, 224, 287-303.

23. Mitręga-Niestrój, K. (2011). Międzynarodowy system finansowy w ujęciu systemowym - jego efektywność oraz stabilność. Studia Ekonomiczne. Uniwersytet Ekonomiczny w Katowicach, 63, 87-102.

24. Solarz, J. K. (2010). Zarządzanie ryzykiem finansowym codzienności. Bezpieczny Bank, 3 (42), $62-79$.

25. Kravchenko, S. I., Kvilinskyi A. S. (2016). Optimizaciya konkurentosposobnosti innovacionnogo proekta $\mathrm{v}$ usloviyah strategicheskoj sinergetizacii. Visnik ekonomichnoï nauki Ukraïni, 1(30), 70-77.

26. Mirovoj bank. Cifrovye dividendy. Gruppa Vsemirnogo banka razvitiya. Available at: http://www-wds.worldbank.org/external/default/WDSContentServer/

WDSP/IB/2016/01/13/090224b08405bbc0/1 0/Rendered/PDF/World0developm010dividends0over view.pdf.

27. BP: Statistical Review of World Energy. Available at: http://www.bp.com/en/global/corporate/energy-economics/statistical-review-of-world-energy.html.

28. ACER/CEER Annual Report on the Results of Monitoring the Internal Electricity and Natural Gas Markets in 2013. Available at: http://www.europarl.europa.eu/meetdocs/2014_2019/documents/itre/dv/acer_market_monitoring_re port 2014_acer_market_monitoring_report_2014_en.pdf.

29. Kvilinskyi, O., Błaszczyk, P., Zagierski, B. (2016). Predposyilki vozniknoveniya virtualnogo regionalizma. MaterIaly dopovidey mizhnarodnoi naukovo-praktichnoi konferentsii "Ekonomika v konteksti innovatsyynogo rozvytku: stan ta perspektyvy", 22-24.

30. Allison, R. (2008).Virtual regionalism, regional structures and regime security in Central Asia. Central Asian Survey, 27 (2), 185-202.

31. Fridman, D. (2010). Sleduyushchie 100 let: Prognoz sobytij XXI veka. Eksmo, Moskva.

32. Shopengauehr, A. (2011). Aforizmy zhitejskoj mudrosti. AST, Moskva.

33. Nadzhafov, D. G., Belousova, Z. S. (2005). Stalin i kosmopolitizm. 1945-1953. Dokumenty Agitpropa CK. Materik, Moskva.

34. Novikov, D. A. (2005). Teoriya upravleniya organizacionnymi sistemami. Moskovskij psihologo-sociologicheskij institut, Moskva.

35. Lefevr, V. A. (2003). Refleksiya. Kogito-Centr, Moskva.

36. Lepa, R. N. (2013). Refleksivnye processy v ehkonomike: koncepcii, modeli, prikladnye aspekty: monografiya. Apeks, Doneck.

37. Marks, K. (1973). Kapital. Kritika politicheskoj ehkonomii. Izdatel'stvo politicheskoj literatury, Moskva.

38. Maslou, A. G. (2009). Motivaciya i lichnost'. Izdatel'skij dom" Piter", Sankt-Peterburg.

39. Stiglic, Dzh. (2003). Globalizaciya: trevozhnye tendencii. Mysl', Moskva.

40. Kvilinskyi, O. S. (2012). Stratehichni aspekty formuvannia mozhlyvostei pokrashchennia diialnosti sub'iektiv maloho biznesu. Skhid, 6 (120), 44-49.

41. Jabłoński, J., Osadcza, N., Kvilinskyi, O. (2016). Decentralization in Ukraine under the sustainble development conditions. "European Cooperation", 8 (15), 120-135.

42. Kharazishvili, Y., Liashenko, V., Zaloznova, Y., Kvilinskyi, O. (2016). Impact of infrastructure component on socioeconomic approach to modernization of the region. "European Cooperation”, 8 (15), 108-119.

Received 01.09.2016

(C) Pająk K., Kamińska B., Kvilinskyi O. 